Пащук Л. В. [1; ORCID ID: 0000-0003-1184-1545] к.е.н., доцент кафедри міжнародної економіки та маркетингу

${ }^{1}$ Київський національний університет імені Тараса Шевченка, м. Київ

\title{
ЕТАПИ ЕВОЛЮЦІЇ РОЗВИТКУ МАЛОГО І СЕРЕДНЬОГО ПІДПРИЕМНИЦТВА В УКРАЇНІ
}

У статті розглянуто еволюцію розвитку малого і середнього підприємництва в Україні, проаналізовано динаміку розвитку підприємництва, зміни у державному регулюванні підприємницької діяльності протягом 1991-2020 років. Особлива увага приділена питанням доступу до бізнес-знань та рівню освіти підприємців. Також було визначено кількість суб'єктів господарювання 3 розрахунку на 10 тисяч осіб наявного населення протягом зазначеного періоду. На основі проведеного аналізу виділено чотири етапи розвитку малого $\mathrm{i}$ середнього підприємництва в Україні. До них було віднесено етап зародження, етап зростання, етап адаптивного розвитку та етап кризового розвитку.

Ключові слова: суб'єкти господарювання; підприємництво; малі i середні підприємства; бізнес-освіта; етапи розвитку підприємництва; міжнародні організації.

Міжнародні організації визначають, що автоматизація виробництв та збільшення кількості населення неминуче призведе до потреби у глобальному вимірі створити 600 млн додаткових робочих місць. Така ситуація торкнеться й України, де понад 99\% суб'єктів підприємницької діяльності $€$ представниками малого і середнього підприємництва, при цьому рівень підтримки та довіри до МСП в Україні залишається недостатнім порівняно зі світовими тенденціями. Підприємництво в нашій державі все ще перебуває на етапі розвитку, адже лише з 1991 року, після здобуття Україною незалежності та переходу до ринкових відносин, в Україні почали активно виникати та розвиватись підприємства, в тому числі малі та середні.

Дослідженням питань розвитку підприємництва в Україні присвячені роботи таких науковців, як З.Варналій, Є.Сахаров, Д. Ляпін, Н. Карпенко, М. Газуда, Н. Волощук, В. Білик та інші. Проте, незважаючи на вагомий внесок вже існуючих доробок, варто зауважити, що вони беруть в основному до уваги чисельні показники, зокрема зростання кількості суб'єктів господарювання. 
При цьому результати соціологічних опитувань свідчать, що у 2011 та 2018 роках підприємцям не довіряло 40\%, а довіряло - 15\% українців, решта мали нейтральне ставлення. Цікавим $€$ той факт, що з 1994 року цей показник майже не змінився [1]. Натомість, представники МСП створюють понад $80 \%$ робочих місць серед усіх суб'єктів підприємництва [2]. Тож, у процесі огляду еволюції розвитку МСП варто більше уваги приділити питанням бізнес-освіти.

Метою даної статті $\epsilon$ узагальнення та систематизація етапів розвитку малого і середнього підприємництва в Україні.

Переважна більшість провідних дослідників, зокрема 3. Варналій, Є.Сахаров, Д.Ляпін доводять, що розвиток малого і середнього підприємництва залежить від рівня розвитку економіки, іï відкритості, ринкових процесів тощо. Н. Карпенко [3] застосовує підхід, запропонований Б. Пясецьким [4, С. 66], згідно якої до уваги береться взаємозв'язок, що існує між станом розвитку економіки держави та стадією життєвого циклу МСП в ній. Такий підхід вважаємо влучним. Беручи його до уваги, виокремимо етапи еволюції, стадії розвитку малого і середнього підприємництва з 1991 року до початку 2020 року.

Таблиця 1

Кількість суб'єктів господарювання, 1997-2019

\begin{tabular}{|l|c|c|c|}
\hline & $\begin{array}{c}\text { Суб'єктів } \\
\text { ЄДРПОу, } \\
\text { всього }\end{array}$ & $\begin{array}{c}\text { Кількість малих } \\
\text { підприємств, } \\
\text { од.*** }\end{array}$ & $\begin{array}{c}\text { На } 10 \text { 000 осіб } \\
\text { наявного } \\
\text { населення, од. }\end{array}$ \\
\hline $\mathbf{1 9 9 7}$ & 615686 & 136238 & 27 \\
\hline $\mathbf{2 0 0 1}$ & 834886 & 217930 & 44 \\
\hline $\mathbf{2 0 0 6}$ & 1070705 & 295109 & 72 \\
\hline $\mathbf{2 0 1 0}$ & 2183928 & 357241 & 78 \\
\hline $\mathbf{2 0 1 1}$ & 1701620 & 354283 & 77 \\
\hline $\mathbf{2 0 1 2}$ & 1600127 & 344048 & 76 \\
\hline $\mathbf{2 0 1 3}$ & 1722070 & 373809 & 82 \\
\hline $\mathbf{2 0 1 4}$ & 1932161 & 324598 & 76 \\
\hline $\mathbf{2 0 1 5}$ & 1974318 & 327814 & 68 \\
\hline $\mathbf{2 0 1 6}$ & 1865530 & 291154 & 76 \\
\hline $\mathbf{2 0 1 7}$ & 1805059 & 322920 & 80 \\
\hline $\mathbf{2 0 1 8}$ & 1839593 & 339374 & \\
\hline
\end{tabular}

Джерело: [7]

Протягом зазначеного періоду становлення та розвитку малого і середнього підприємництва пройшли певні етапи, які частково обумовлені законодавчою базою, заходами зі боку держави, рівнем розвитку економіки та змінами в освітньому процесі. В. Білик у 
своєму дослідженні виділив чотири етапи розвитку МСП в Україні до 2012 року [5]. Узагальнимо їх та доповнимо подальшими стадіями розвитку підприємництва, взявши до уваги нерівномірність розподілу кількості підприємств у різні періоди. У табл. 1 на основі частково доступної з 1997 року офіційної статистичної інформації узагальнено кількість зареєстрованих суб'єктів ЄДРПОУ, малих підприємств та здійснено розрахунок кількості підприємств на 10000 осіб населення [6, С. 68]. Статистична реєстрація кількості суб'єктів господарювання, яка використовується і зараз, почалася з 2001 року, тому дані щодо 1997 року, взяті з монографії М. Газуди та Н. Волощук, є такими, що можуть потребувати додаткової перевірки. Також варто зазначити, що загалом класифікація на малі, середні та великі підприємства почалася з 2010 року, тому ці показники за 2001 та 2006 також є відносними, але дають змогу уявити загальну динаміку зміни кількості суб'єктів господарювання.

Таблиця демонструє значні коливання у кількості підприємств, проте з 2010 року кількість суб'єктів підприємницької діяльності на 10000 населення залишається більш-менш стабільною. Також важливими індикаторами розвитку, а значить й еволюції, виступають дії держави, зокрема прийняті нормативні акти, створені державні органи тощо. Крім дій держави, у даному огляді варто звернути увагу і на можливості доступу до знань стосовно ведення підприємницької діяльності у різні періоди. Тож, нижче охарактеризуємо етапи розвитку МСП в Україні.

1. Перший етап (1991-1999рр.) розпочався з ухвалення Закону України «Про підприємництво» 7 лютого 1991 р. Також у травні 1991 року було створено Державний комітет України зі сприяння малим підприємствам і підприємництву. Цей період характеризувався падінням економіки, високими темпами інфляції, руйнуванням народного господарства, розірванням звичних для радянських громадян економічних правил та взаємин, а також зубожінням населення. Кількість малих та середніх підприємств зростала, проте прирости їх кількості могли би бути суттєвішими. Як зазначає В.Білик, найвідчутніші темпи приросту щодо загальної кількості суб'єктів підприємницької діяльності мали місце у 19911996 рр., що було обумовлено зміною умов функціонування господарської діяльності, появи можливості підприємництва на території нещодавно утвореної нашої держави [5]. Така тенденція супроводжувалась, у тому числі низьким рівнем знань населення про підприємницьку діяльність. Тільки у 1992 році почали з'являтись перші «бізнесові» спеціальності у закладах вищої освіти. Зокрема, у 1992 році в Національному технічному університеті «Київський 
політехнічний інститут» було засновано факультет менеджменту та маркетингу, що розпочав підготовку фахівців з менеджменту та маркетингу [8]. Засновники спеціальностей та кафедр здобували знання та сучасну для того часу освіту за кордоном. Економічні кафедри та спеціальності також почали процес трансформації. Перші бізнес-школи і досі залишаються провідними. Наприклад, у липні 1993 року за постановою Кабінету Міністрів України було засновано Міжнародний інститут бізнесу. 31995 р. тенденція дещо змінилась і розпочалося сповільнення показників зростання, проте цей етап можна назвати етапом зародження.

2. Другий етап (2000-2006 рр.) можна назвати етапом зростання, адже він відзначився тим, що відбулося бурхливе зростання загальної кількості підприємств, в тому числі представників малого та середнього бізнесу. Наприклад, у 2003 р. темпи зростання кількості підприємств дорівнювали $11 \%$, порівняно з попереднім звітним роком, а з 2004 темп зростання мав позитивне значення лише в 4,3-4,8\% [9]. В. Білик зазначає, що одночасно зі зростанням кількості малих і середніх підприємств помітними були тенденції зниження середньооблікової кількості працівників і їхньої продуктивності [5]. Водночас питома вага продукції та послуг, яку створювали ці підприємства у промисловості України, мала помітну динаміку у бік зростання. Щодо розподілу кількості підприємств за формами власності, то можемо зазначити, що в 2001 році у колективній формі власності було 47,94\%, в 2006 р. - 29,11\%; у приватній формі власності в 2001 р. - 23,01\%, в 2006 р. - 23,18\%; у державній формі власності в 2001 р. - 1,19\%, в $2006-0,71 \%$ [10, C. 62].

Зміни в освіті для підприємців також відзначились тим, що фахівці 3 фінансів, маркетингу, бізнес-адміністрування, підприємництва, біржової діяльності, страхування, вже мали можливості здобути знання у вищих навчальних закладах, в бізнесшколах, спеціалізованих тренінгових компаніях тощо. На провідних економічних факультетах вже з'явились спеціальності, що могли задовольнити потребу у кваліфікованих кадрах для бізнесу.

3. Третьому етапу розвитку підприємництва в Україні (20062013 рр.) можна дати назву етапу адаптивного розвитку. Саме на нього припало важливе ухвалення нормативних актів, зокрема Господарського кодексу України та Законів України «Про внесення змін до деяких законодавчих актів України з питань регулювання підприємницької діяльності» і «Про державну підтримку малого підприємництва». Однією із причин появи подібної нормативної бази стала необхідність адаптації українських умов господарювання, в 
тому числі ведення підприємницької діяльності до європейських та міжнародних стандартів. В напрямку регулювання діяльності МСП відбулися зміни у критеріях та підходах до класифікації малих, середніх і великих підприємств. Можна стверджувати, що це був перший крок до запровадження національної класифікації суб'єктів підприємництва згідно з рекомендаціями Європейського Союзу. Варто зазначити, що у цей період фактично працювали тільки $40 \%$ від загальної кількості підприємств, при цьому кількість малих та середніх підприємств залишалась незмінною. Протягом 2003-2008 років кількість підприємств поступово зростала, чисельність зайнятих в МСП також мала позитивну динаміку зростання. У 2008 році кількість суб'єктів підприємницької діяльності становила понад 1,18 млн, з подальшою тенденцією до зростання [9]. У 2008-2009 роках відбулася глобальна фінансова криза. Це явище світового масштабу спричинило багато негативних трендів і в українській економіці. У 2009 році обсяги виробництва та реалізації продукції порівняно з 2008 р. знизилися на 6,3\%; частка малих і середніх підприємств у обсягах реалізованої продукції та наданих послуг зменшилась, рівень інвестиційної активності став нижчим, фінансово-економічні показники господарської діяльності теж погіршилися, підприємства перейшли в тінь. За оцінкою дослідження про тіньову економіку, проведеного Л. Медіною і Ф. Шнайдером під егідою МВФ, протягом 2008-2014 років рівень тіньової економіки України коливався в межах від $36,65 \%$ до 43,5\% від ВВП, а частка підприємств, що працювали у тіньовому секторі становила 50-70\% [11] У цей період бізнес-освіта в Україні вже мала змогу надавати якісні сучасні знання щодо ведення підприємницької діяльності, класичні університети вже створили наукові та практичні школи щодо ведення бізнесу взагалі та окремих його аспектів зокрема. Це період тривав до початку 2014 року.

4. Наступний етап розвитку бере свій початок у 2014 році після Революції Гідності, коли відбулося підписання Угоди з Європейським Союзом, що ознаменувало новий підйом у розвитку підприємництва в Україні, пов'язаний з європейським ії вибором в умовах низки зовнішніх загроз та негативних явищ, зокрема зростаючого рівня міграції, тимчасової втрати частини територій, воєнних дій, економічної кризи. У відповідь на перелічені та інші фактори у 2015 році кількість малих та середніх підприємств почала знижуватись, проте у 2017 році, як демонструє табл. 2, вона почала поступово збільшуватись, перевищивши у 2018 році показники 2014 року. 
Кількість суб'єктів МСП за 2014-2018 рр.

\begin{tabular}{|l|c|c|c|c|c|}
\hline & 2014 & 2015 & 2016 & 2017 & 2018 \\
\hline $\begin{array}{l}\text { Середні } \\
\text { підприємства }\end{array}$ & 15906 & 15203 & 14832 & 14937 & 16057 \\
\hline $\begin{array}{l}\text { Малі } \\
\text { підприємства }\end{array}$ & 324598 & 327814 & 291154 & 322920 & 339374 \\
\hline ФОП-СП & 712 & 307 & 281 & 317 & 419 \\
\hline ФОП-МП & $\begin{array}{c}159044 \\
8\end{array}$ & $\begin{array}{c}163057 \\
1\end{array}$ & $\begin{array}{c}155888 \\
0\end{array}$ & $\begin{array}{c}146648 \\
6\end{array}$ & $\begin{array}{c}148329 \\
7\end{array}$ \\
\hline
\end{tabular}

\section{Джерело: [7]}

На рисунку наведено графічну демонстрацію динаміки кількості суб'єктів малого і середнього підприємництва в Україні, тобто видно поступове відновлення кількості підприємств у 2017 році після падіння протягом 2015-2016 років.

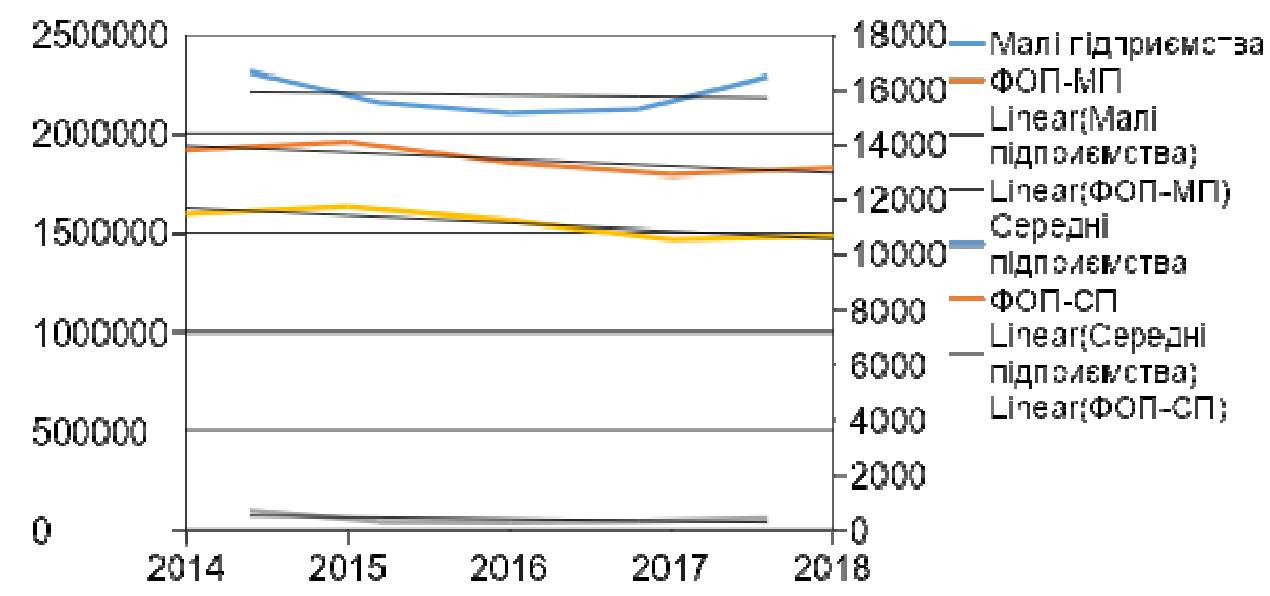

Рисунок. Кількість суб'єктів МСП за 2014-2018 рр.

Джерело: побудовано автором на основі табл. 1 та [7]

Як бачимо з табл. 2 та рисунку, кількість суб'єктів малого та середнього підприємництва коливається, проте їх загальна кількість залишається більш-менш стабільною, не відхиляючись від середнього значення.

У 2018 році було прийнято Стратегію розвитку малого і середнього підприємництва до 2020 року, а також створено у травні 2018 року Офіс розвитку МСП при Міністерстві розвитку економіки, торгівлі та сільського господарства України. Мета Офісу полягає у сприянні реалізації затвердженої Стратегії, в тому числі у царині розбудови інфраструктури для розвитку МСП в Україні. Офіс має 
фінансову підтримку Європейського Союзу в рамках проєкту FORBIZ та Ініціативи EU4Business [12-13].

Варто також розглянути питання малого та середнього підприємництва у порівнянні з іншими країнами. Так, наприклад, важливим є показник частки МСБ в загальному ВВП країни. У 2018 році в Україні такий показник склав майже 10\%, тоді як адекватним значенням для більшості розвинутих країн $€ 50 \%$ і більше. Проте, якщо за критерій брати обсяги реалізації товарів та послуг в Україні, то суб'єкти МСП охопили майже дві третини від загального обсягу [2, С. 23]. Тенденція переважання та зростання участі малих і середніх підприємств в реалізації продукції помітна зокрема з 2013 по 2018 роки, коли їх частка збільшилась з 60\% до 65\%. Зростання стосувалось всіх без винятку сегментів, при цьому домінував середній бізнес $(40 \%$ у 2018 році). Водночас це стосується лише внутрішнього ринку, оскільки присутність малих і середніх підприємств на зовнішніх ринках $є$ невисокою і їхня частка в експорті товарів складає лише $26 \%$.

Ще одним показником $є$ кількість зайнятих у сфері малого підприємництва по відношенню до кількості населення працездатного віку. Відповідно до даних Європейської бізнесасоціації в розвинутих країнах цей показник більше $50 \%$ (країни $€ C$ ), або навіть досягає $80 \%$ (Японія). В Україні ж цей показник оцінено в 9\% (2018 рік), що демонструє, за деякими фахівцями, початковий етап розвитку МСБ. Проте, якщо розглядати структуру працевлаштованого населення в Україні, то можна відзначити, що саме на малий та середній бізнес припадає найбільша частка зайнятості, до того ж така ситуація має висхідну тенденцію - з 2013 по 2018 роки частка МСП в структурі працевлаштувань збільшилась $375 \%$ до 82\%. Зростання відбулось насамперед за рахунок мікробізнесу і частково середнього, тоді як частка малого бізнесу трохи скоротилася.

Освіта з підприємництва стала ще більш розвиненою на даному етапі розвитку МСП в Україні, були засновані новітні навчальні програми, підприємці отримали доступ до короткочасних тренінгів під різні цілі та задачі, за різною вартістю. Також в Україні почали активно вести просвітницьку діяльність проєкти міжнародних організацій, що дає змогу стверджувати про поступове формування підприємницької культури в державі. Цей етап можна назвати етапом кризового розвитку.

Висновки. Отже, як продемонстрував проведений огляд еволюції розвитку малого і середнього підприємництва, з моменту 
здобуття незалежності Україною у 1991 році до 2019 року, сектор малого і середнього підприємництва пройшов різні етапи свого становлення, у даному дослідженні їх виділено чотири та дано назви, зокрема етап зародження, етап зростання, етап адаптивного розвитку та етап кризового розвитку. Етап зростання тривав чотири роки з 1991 до 1995, у цей період починались перші законодавчі ініціативи, значно збільшувалась кількість підприємств, що обумовлено фактично відсутністю подібної діяльності до того. Етап зростання тривалістю у десять років ознаменувався зростанням питомої ваги виробленої продукції та наданих послуг МСП у загальній структурі економіки України. Етап адаптивного розвитку з 2007 до 2013 року по суті став перехідним, оскільки саме в цей період розпочато адаптацію умов ведення бізнесу згідно міжнародних та європейських стандартів. Наступний етап кризового розвитку розпочався у 2014 року з глибокої кризи, триває він і донині, проте він $є$ етапом розвитку, оскільки саме в цей період було створено Офіс розвитку МСП, підприємці почали усвідомлювати важливість отримання знань щодо ведення бізнесу, а також почала створюватись інфраструктура для ведення підприємницької діяльності згідно сучасних вимог. Попередній 29-річний досвід роботи МСП України був, по суті, процесом створення та розвитку, тож у даному дослідженні також було наведено стислий аналіз можливостей отримання знань підприємцями у різні періоди.

1. Українське суспільство. Двадцять років незалежності. Незалежний моніторинг : у 2 т. / за ред. д.філос.н. Є. І. Головахи, д.соц.н. М. О. Шульги. К. : Інститут соціології НАН України, 2011. Т. 2. 480 с. 2. Горюнов Д., Кравченко О., Вдовенко Ю., Денисюк Г. Огляд МСП в Україні 2018/2019: Фокус на європейській інтеграції. Київ : 2020. URL: https://drive.google.com/file/d/1/2ckLnFpxcbePvy_ymQIJMi5Wci5RKxP/view (дата звернення: 16.09.2020). 3. Карпенко Н. В. Генезис малого та середнього бізнесу в Україні. Культура народов Причерноморья. 2007. № 103. С. 79-84. 4. Piasecki E. В. Policy on small and medium-sized enterprises in Central and Eastern European Countries. Warsaw : 1992. 263 р. 5. Білик В. Сучасні тенденції розвитку малого і середнього бізнесу в Україні. Ефективна економіка. 2012. № 3. URL: http://www.economy.nayka. com.ua/?op=1\&z=1012 (дата звернення: 16.09.2020). 6. Газуда М.В., Волощук Н.Ю. Регіональний розвиток сфери малого підприємництва. Ужгород : Видавництво «ФОП Сабов А.М.», 2017.254 с. 7. Показники структурної статистики по суб'єктах господарювання з розподілом за ïx розмірами. Державна служба статистики України. URL: http://www.ukrstat.gov.ua/operativ/operativ2012/fin/osp/osp_u/osp_u.htm (дата звернення: 16.09.2020). 8. Факультет менеджмента и маркетинга. Национальный технический университет Украины «Киевский политехнический институт имени Игоря Сикорского» : вебсайт. URL: https://kpi.ua/ru/fmm (дата звернення: 16.09.2020). 9. Україна у цифрах у 2010 році / Держкомстат України ; за ред. О. Г. Осауленко. К. : Консультант, 2011. 260 с. 10. Статистичний щорічник України за 2007 рік / Державний комітет статистики України ; за ред. О. Г. Осауленко. К. : 
Консультант, 2007. 571 c. 11. Medina L., Schneider F. Shadow Economies around the World: what did we learn over the last 20 years? IMF Working Paper. 2018. URL: https://www.researchgate.net/publication/323189178_Shadow_Economies_Around_t he_World_What_Did_We_Learn_Over_the_Last_20_Years (accessed: 22.08.2020). 12. OECD. Compendium of Enterprise Statistics in Ukraine 2018. URL: http://www.oecd.org/eurasia/competitiveness-programme/easternpartners/Compendium-Entreprise-Statistics-Ukraine-2018-EN.pdf (accessed: 22.08.2020). 13. Yankovyi O., Koval V., Trokhymets O., Karpenko M., Matskevich Y. Economic assessment of investment on the basis of production functions. Turismo: Estudos \& Práticas. 2020. 2.

\section{REFERENCES:}

1. Ukrainske suspilstvo. Dvadtsiat rokiv nezalezhnosti. Nezalezhnyi monitorynh : u $2 \mathrm{t}$. I za red. d.filos.n. Ye. I. Holovakhy, d.sots.n. M. O. Shulhy. K. : Instytut sotsiolohii NAN Ukrainy, 2011. T. 2. 480 s. 2. Horiunov D., Kravchenko O., Vdovenko Yu., Denysiuk H. Ohliad MSP v Ukraini 2018/2019: Fokus na yevropeiskii intehratsii. Kyiv : 2020. URL: https://drive.google.com/file/d/1I2ckLnFpxcbePvy_ymQIJMi5Wci5RKxP/view (data zvernennia: 16.09.2020). 3. Karpenko N. V. Henezys maloho ta serednoho biznesu v Ukraini. Kultura narodov Prychernomoria. 2007. № 103. S. 79-84. 4. Piasecki E. B. Policy on small and medium-sized enterprises in Central and Eastern European Countries. Warsaw : 1992. 263 p. 5. Bilyk V. Suchasni tendentsii rozvytku maloho i serednoho biznesu v Ukraini. Efektyvna ekonomika. 2012. № 3. URL: http://www.economy.nayka. com.ua/?op=1\&z=1012 (data zvernennia: 16.09.2020). 6. Hazuda M. V., Voloshchuk N. Yu. Rehionalnyi rozvytok sfery maloho pidpryiemnytstva. Uzhhorod : Vydavnytstvo «FOP Sabov A. M.», 2017. 254 s. 7. Pokaznyky strukturnoi statystyky po subiektakh hospodariuvannia z rozpodilom za yikh rozmiramy. Derzhavna sluzhba statystyky Ukrainy. URL: http://www.ukrstat.gov.ua/operativ/operativ2012/fin/osp/osp_u/osp_u.htm (data zvernennia: 16.09.2020). 8. Fakultet menedjmenta i marketinga. Natsionalnyiy tehnicheskiy universitet Ukrainyi «Kievskiy politehnicheskiy institut imeni Igorya Sikorskogo»: veb-sait. URL: https://kpi.ua/ru/fmm (data zvernennia: 16.09.2020). 9. Ukraina u tsyfrakh u 2010 rotsi / Derzhkomstat Ukrainy ; za red. 0. H. Osaulenko. K. : Konsultant, 2011. 260 s. 10. Statystychnyi shchorichnyk Ukrainy za 2007 rik / Derzhavnyi komitet statystyky Ukrainy ; za red. O. H. Osaulenko. K. : Konsultant, 2007. 571 c. 11. Medina L., Schneider F. Shadow Economies around the World: what did we learn over the last 20 years? IMF Working Paper. 2018. URL: https://www.researchgate.net/publication/323189178_Shadow_Economies_Around_t he_World_What_Did_We_Learn_Over_the_Last_20_Years (accessed: 22.08.2020). 12. OECD. Compendium of Enterprise Statistics in Ukraine 2018. URL: http://www.oecd.org/eurasia/competitiveness-programme/easternpartners/Compendium-Entreprise-Statistics-Ukraine-2018-EN.pdf laccessed: 22.08.2020). 13. Yankovyi O., Koval V., Trokhymets O., Karpenko M., Matskevich Y. Economic assessment of investment on the basis of production functions. Turismo: Estudos \&Práticas. 2020. 2. 


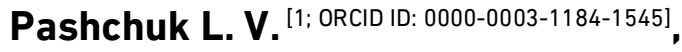
Candidate of Economics (Ph.D.), Associate Professor

${ }^{1}$ Taras Shevchenko National University of Kyiv

\section{EVOLUTION STAGES OF SMALL AND MEDIUM ENTERPRISES DEVELOPMENT IN UKRAINE}

The article considers the evolution of small and medium entrepreneurship development in Ukraine, analyzes the dynamics of business development, changes in state regulation of business activity during 1991-2020. During the stated period, Ukrainian entrepreneurship passed a long way and nowadays over $99 \%$ of business entities in Ukraine are small and medium-sized enterprises. At the same time, the level of support and trust in SMEs in Ukraine remains insufficient in comparison with global trends, as article demonstrates. Meanwhile, small and medium-sized enterprises in Ukraine are still at the stage of development, because since 1991, when Ukraine gained independence and transition to market relations started. Ukrainian business has begun to actively emerge and develop. Current articles suggests the classification of evolution stages of small and medium enterprises development in Ukraine. In the study, four SMEs development evolution stages were defined, thereof: stage of conception, stage of growth, stage of adaptive development and stage of crisis development. The conception phase lasted for four years from 1991 to 1995 , during which time the first legislative initiatives began, the number of enterprises increased significantly, due to the fact that there was no such activity before. The ten-years growth phase was marked by an increase in the share of manufactured products and services provided to SMEs in the general structure of Ukraine's economy. The stage of adaptive development from 2007 to 2013 essentially became a transitional one, as it was during the period of the adaptation of business conditions according to international and European standards began. The next stage of crisis development began in 2014 with a deep crisis. It continues nowadays. Namely, during current period a lot of very important initiatives took place. For example, SME Development Office was established, entrepreneurs began to realize the importance of business knowledge, and government began to create infrastructure for conducting business in accordance with modern requirements. The previous 29-year experience of SMEs in Ukraine was, in fact, a process of creation and development, so this study also provided a brief analysis of the opportunities for entrepreneurs to acquire knowledge in different periods.

Keywords: business entities; entrepreneurship; small and medium enterprises; business education; stages of business development; international organizations. 
Пащук Л. В. [1; ORCID ID: 0000-0003-1184-1545], к.э.н., доцент

${ }^{1}$ Киевский национальный университет имени Тараса Шевченко, г. Киев

\section{ЭТАПЫ ЭВОЛЮЦИИ РАЗВИТИЯ МАЛОГО И СРЕДНЕГО ПРЕДПРИНИМАТЕЛЬСТВА В УКРАИНЕ}

В статье рассмотрена эволюция развития малого и среднего предпринимательства в Украине, проанализирована динамика развития предпринимательства, изменения в государственном регулировании предпринимательской деятельности в течение 1991-2020 годов. Особое внимание уделено вопросам доступа к бизнес-знаниям и уровню образования предпринимателей. Также было определено количество субъектов хозяйствования в расчете на 10000 человек населения за указанный период. На основе проведенного анализа выделены четыре этапа развития малого и среднего предпринимательства в Украине. К ним были отнесены этап зарождения, этап роста, этап адаптивного развития и этап кризисного развития.

Ключевые слова: субъекты хозяйствования; предпринимательство; малые и средние предприятия; бизнес-образование; этапы развития предпринимательства; международные организации.

Стаття надійшла до редакції 21.09.2020 р. 